\title{
Konsep dasar K3 di Rumah Sakit
}

\author{
Rizqiyatul Laili \\ e-mail : laili.rizqivatul@gmail.com
}

\section{LATAR BELAKANG}

Rumah Sakit harus menjamin kesehatan dan keselamatan baik terhadap pasien, penyedia layanan atau pekerja maupun masyarakat sekitar dari berbagai potensi bahaya di Rumah Sakit. Oleh karena itu, Rumah Sakit dituntut untuk melaksanakan Upaya Kesehatan dan Keselamatan Kerja (K3) yang dilaksanakan secara terintegrasi dan menyeluruh sehingga risiko terjadinya Penyakit Akibat Kerja (PAK) dan Kecelakaan Akibat Kerja (KAK) di Rumah Sakit dapat dihindari. Penyakit akibat kerja di rumah sakit dapat menyerang semua tenaga kerja baik medis maupun non medis.

Sasaran utama K3RS adalah tenaga medis, tenaga non medis, pasien, pengunjung / pengantar pasien, serta masyarakat sekitar Rumah Sakit. Bahaya potensial yang dapat menyebabkan penyakit akibat kerja (PAK) yang terjadi di rumah sakit, umumnya berkaitan dengan faktor biologi (kuman patogen yang umumnya berasal dari pasien), faktor kimia (pemaparan dalam dosis kecil namun terus menerus seperti antiseptik pada kulit, gas anestesi pada hati), faktor ergonomi (tata cara duduk, tata cara mengankat pasien), faktor fisik dalam dosis kecil yang terus menerus (suhu udara panas, listrik tegangan tinggi, dan radiasi), faktor psikologis ( hubungan kerja antar karyawan atau atasan serta tata cara kerja di kamar bedah, dibagian penerimaan pasien, di unit gawat darurat dan ruang perawatan).

Standar Kesehatan dan Keselamatan Kerja di RS (K3RS) perlu ditetapkan untuk mencegah dan mengurangi risiko kecelakaan dan penyakit akibat kerja di RS.Demi terciptanya jaminan keselamatan kerja maka diperlukan pelayanan strategis yang profesional serta prosedur kerja yang tetap, tidak hanya tergantung pada peraturan-peraturan yang mengayominya dan finansial yang diberikan, 
melainkan banyak faktor yang harus ikut terlibat, diantaranya adalah pelaksanaan organisasi.Suatu organisasi yang berhasil dapat diukur dengan melihat pada sejauh mana organisasi tersebut dapat mencapai tujuannya.Pelaksanaan K3 di RS dapat dinilai dari kefektivitasan organisasi K3 tersebut (Kun dwi apriliawati,2017)

\section{METODE}

Metode penelitian yang digunakan adalah literature review. Dengan melakukan analisis dan kajian bebas pada jurnal dan textbook yang sudah terjamin datanya dengan tahun 2012-2020. Pengambilan informasi melalui jurnal dan textbook adalah untuk mendapatkan berbagai informasi yang lengkap dan akurat dengan cara melakukan penyimpulan dari jurnal dan textbook tersebut. Penyimpulan yang dilakukan adalah dengan menggunakan bahasa sendiri tanpa ada meniru karya orang lain.

\section{HASIL}

Berdasarkan jurnal dan textbook tersebut, didapatkan bahwa berdasarkan data dari World Health Organization (WHO) : Dari 35 juta pekerja kesehatan 3 juta terpajan patogen darah ( 2 juta terpajan virus $\mathrm{HBV}, 0,9$ juta terpajan virus $\mathrm{HBC}$ dan 170,000 terpajan virus HIV/ AIDS). Dapat terjadi : 15,000 HBC, 70,000 HBB \& 1000 kasus HIV. Lebih dari 90\% terjadi di negara berkembang.8-12\% pekerja rumah sakit, sensitif terhadap lateks. Probabilitas penularan HIV setelah luka tusuk jarum suntik yang terkontaminasi HIV 4: 1000. Risiko penularan HBV setelah luka tusuk jarum suntik yang terkontaminasi HBV 27-37: 100. Risiko penularan HCV setelah luka tusuk jarum suntik yang mengandung HCV 3 - 10 : 100 (Sunandar, 2017).

Kebijakan K3 telah ditetapkan dan masih dalam proses perbaikan yang lebih baik lagi untuk mewujudkan sarana dan prasarana serta SDM yang lebih baik untuk melaksanakan K3. Namun, diakui bahwa sarana dan prasarana yang tersedia masih minim, misalnya untuk APD diruang tertentu belum sesuai dengan standart yang telah ditetapkan karena membutuhkan biaya yang sangat besar. Semua anggota yang ada di struktur organisasi Komite Keselamatan dan Kesehatan Kerja RS 
terlibat didalam perencanaan kebijakan K3 dalam bentuk sumber daya yang berupa karyawan mendapatkan pelatihan K3. Kebijakan K3 ini sejalan dengan penelitian Sunandar (2017), dimana RS telah menetapkan kebijakan K3 secara tertulis terkait pelaksanaan Keselamatan dan Kesehatan Kerja (K3) yang ditanda tangani langsung oleh direktur.

Kebijakan tersebut bersifat top down maksudnya pimpinan RS telah memiliki standar pelayanan K3 di Rumah Sakit, kemudian diadopsi dan disesuaikan dengan kondisi Rumah Sakit. Kebijakan tersebut di rumuskan oleh timK3RS dan melakukan konsultasi dengan pihak pihak yang terkait, kemudian di usulkan ke direktur dan ditandatangani. Kebijakan tersebut ditembuskan keseluruh unit/pokja terkait, dikomunikasikan dalam bentuk sosialisasi atau kegiatan simulasi.Pihak K3RS juga melakukan tinjauan ulang kebijakan secara berkala untuk menyesuaikan kebijakan Keselamatan dan Kesehatan Kerja yang diterapkan Rumah Sakit dengan perkembangan kondisi Rumah Sakit dan perubahan peraturan perundangundangan.

\section{PEMBAHASAN}

Rumah Sakit dalam kegiatannya menyediakan fasilitas yang aman, berfungsi dan suportif bagi pasien, keluarga, staf, dan pengunjung. Secara fasilitas yang terkait tentang K3 yang diberikan Rumah Sakit sudah baik, akan tetapi fasilitas yang diberikan belum lengkap, fasilitas diberikan sesuai dengan anggaran Rumah Sakit tentang K3.

Pada prinsipnya permasalahan timbul karena lemahnya pihak manajemen dalam menjalankan K3 dengan baik dan benar serta rendahnya tingkat kesadaran tenaga medis terhadap pentingnya pelaksanaan $\mathrm{K} 3$, pelatihan yang dilakukan terhadap tenaga medis juga kurang merata, tidak semua tenaga medis mendapat kesempatan yang sama untuk mengikuti pelatihan.

Pengetahuan karyawan Rumah Sakit tentang pengertian serta manfaat K3RS juga sangat berpengaruh terhadap berhasil tidanya k3 oleh karyawan Rumah Sakit. Diharapkan Semua karyawan mengetahui tentang pengertian dan manfaat K3 
peraturan atau standar yang harus digunakan untuk Rumah Sakit. Namun, kebanyakan karyawan Rumah Sakit hanya mengetahui standar yang di tetapkan oleh kementrian kesehatan tentang akreditasi RS, sedangkan untuk standar yang ditetapkan oleh pemerintah mengenai SMK3 belum mengetahui. Padahal peraturan atau standar yang digunakan Rumah Sakit harus mengacu pada peratuan pemerintahan yaitu tentang SMK3 dan peraturan kementerian kesehatan yaitu standar akreditasi RS dan Standar K3RS.

Perawat mempunyai peran yang sangat penting untuk menjaga keselamatan pasien. Persepsi perawat tentang K3 menunjukkan bagaimana perawat mampu mencari tahu tentang pentingnya K3 baik melalui brosur, leaflet, SOP yang disediakan di ruangan maupun media informasi lainnya. Perawat juga dituntut untuk faham bagaimana cara pencegahan kecelakaan serta penanganan yang dapat dilakukan apabila kecelakaan terjadi. Pemahaman tersebut akan menimbulkan persepsi yang baik dalam diri perawat tentang K3 sehingga hal ini akan meningkatkan perilakunya dalam menjaga keselamatan pasien.

Selain persepsi, sikap juga mempengaruhi yaitu seorang perawat dalam melaksanakan manajemen K3 harus memiliki sikap yang sesuai dengan nilai-nilai kesehatan dimana seluruh nilai positif yang ada dalam dirinya menjadi pendorong perilaku sehat dan menjadi upaya dalam meningkatkan kesehatan dan keselamatan selama bekerja.

Dilihat dari struktur organisasi yang berada di RS, struktur organisasi K3 belum ada karena belum terbentuk. Akan tetapi pihak manajemen RS sudah mempunyai orang yang menangani masalah itu yaitu HRD Rumah Sakit dan Direktur Rumah Sakit. Struktur organisasi tentang K3 akan dibuat pada tahun ke dua dari awal RS beroperasi atau memberikan jasa pelayanannya.

Kebijakan K3 dibuat secara terlulis, tertanggal, ditandatangani oleh pengusaha atau pengurus RS, secara jelas menyatakan tujuan dan sasaran K3 serta komitmen terhadap peningkatan K3. Kebijakan K3 menjadi landasan utama yang diharapkan mampu menggerakkan semua elemen didalam perusahaan sehingga 
dapat terwujudnya program K3 dan program tersebut dapat dilaksanakan dengan baik.

Beberapa keperluan yang berkaitan dengan K3RS,dan fasilitas RS yang berkaitan dengan K3 yaitu seperti : safety sign, APAR, dan APD. Untuk sistem keamanan tanggap darurat yaitu Rumah Sakit menggunakan alarm, alarm akan direalisasikan bersamaan dengan adanya K3RS.

Karyawan sebagai aset penting rumah sakit harus dijaga dan dibina agar selalu dalam kondisi yang sehat dan bebas dari pengaruh negatif yang disebabkan oleh bahaya di tempat kerja. Berdasarkan tempat kerja karyawan terbagi menjadi 4 zona risiko yaitu zona risiko rendah, zona risiko sedang, zona risiko tinggi dan zona risiko sangat tinggi. Zona risiko tinggi yaitu karyawan yang bekerja pada bagian ruangan operasi, ruang bedah mulut, ruang perawatan gigi, ruang rawat gawat darurat, ruang bersalin dan ruang patologi.

Pemantauan lingkungan kerja seperti pemeriksaan fisik (pencahayaan, suhu, kelembapan, kebisingan), pemeriksaan biologi dan pemeriksaan kimia dilakukan secara berkala setiap 1 tahun sekali. Rumah Sakit harus membuat evaluasi, pencatatan dan pelaporan kegiatan K3RS yang disampaikan kepada Direktur Rumah Sakit dan diharapkan adanyanya tindak lanjut dari kejadian Penyakit Akibat Kerja (PAK) maupun Kecelakaan Akibat Kerja (KAK).

Dalam Kepmenkes RI No. 1087 Tahun 2010 tentang standart kesehatan dan keselamatan kerja (K3) di Rumah Sakit bahwa penyesuaian terhadap peralatan kerja SDM dikatkan sudah diterapkan apabilah telah melakukan : 1. Identifikasi dan penilaian risiko ergonomi terhadap perlatan kerja dan SDM Rumah Sakit. 2. Membuat program pelaksanaan kegiatan, mengevaluasi dan mengendalikan risiko ergonomi. Pentingnya penyesuaian peralatan kerja SDM adalah untuk menghindari Penyakit Akibat Kerja (PAK) dan Kecelakaan Akibat Kerja (KAK) yang disebabkan karena golongan ergonomi (penyakit yang disebabkan karena prinsipprinsip peralatan kerja, proses kerja dan tempat kerja) misalnya nyeri otot, kelelahan fisik, deformitas tulang, dislokasi dan kecelakaan). 


\section{PENUTUP}

Beberapa point penting yang mendukung konsep dasar K3 ini yaitu lengkapnya sarana prasarana atau fasilitas yang sudah disediakan oleh rumah sakit berupa Alat Pelindung Diri, pegelolaan limbah cair, pemisahan limbah medis dan non medis, sistem komunikasi menggunakan line telf, safety sign, pengawasan terhadap peralatan yang digunakan, format pelaporan insiden, ketidaksesuaian dan identifikasi sumber bahaya. Rumah Sakit diharapkan membuat struktur organisasi yang khusus menangani masalah K3RS agar tugas dari masing - masing unit lebih optimal.

\section{DAFTAR PUSTAKA}

Azza Ivana, Baju Widjasena, Siswi Jayanti. 2014. Analisa Komitmen Manajemen Rumah Sakit (RS) Terhadap Keselamatan Dan Kesehatan Kerja (K3) Pada RS Prima Medika Pemalang. Jurnal Kesehatan Masyarakat (e-Journal), Volume 2, Nomor 1

Hana Ike Dameria Purba, Vierto Irennius Girsang, Ulfa Syahriani Malay. 2018. Studi Kebijakan, Perencanaan dan Pelaksanaan Keselamatan dan Kesehatan Kerja Rumah Sakit (K3RS) di Rumah Sakit Umum (RSU) Mitra Sejati Medan Tahun 2018. Jurnal Mutiara Kesehatan Masyarakat. 3 (2): 113-124

Herman, M.J, Handayani RS. 2016. Sarana dan Prasarana Rumah Sakit Pemerintah dalam Upaya Pencegahan dan Pengendalian Infeksi di Indonesia. Jurnal Kefarmasian Indonesia, (online) Vol. 6, No. 2,

Kun Dwi Apriliawati, Ekawati, B. K. 2017. Efektivitas Pelaksanaan Manajemen Organisasi Keselamatan dan Kesehatan Kerja Rumah Sakit (K3RS) Di Rumah Sakit X Semarang. Jurnal Kesehatan Masyarakat, 5, 2356-3346.

Natasia, N., Loekqijana, A., \& Kurniawati, J. 2014. Faktor yang Mempengaruhi Kepatuhan Pelaksanaan SOP Asuhan Keperawatan di ICU -ICCU RSUD Gambiran Kota Kediri . Jurnal Kedokteran Brawijaya, Vol. 28, Suplemen No. 1. 
Riska Nazirah, Yuswardi. 2017. Perilaku Perawat dalam Penerapan Manajemen Kesehatan dan Keselamatan Kerja (K3) di Aceh. Idea Nursing Journal. Vol. VIII No. 3

Salmawati, L. dkk. 2015.Hubungan Penerapan Sistem Manajemen Keselamatan Dan Kesehatan Kerja Dengan Motivasi Kerja Dan Stres Kerja Pada Perawat Di Rumah Sakit Umum Anutapura Palu. Jurnal Manajemen Pelayanan Kesehatan 18(1), 4- 6.Universitas Tadulako Palu.

Sartika, Dewi; Hariyati , Tutik Sri; Noviestasari, E. (2014). Self Efficacy Perawat Dalam Penggunaan Sistem Informasi Keperawatan Di Rsia Bunda Jakarta: Studi Fenomenologi. Jurnal Keperawatan Indonesia, Volume 17.

Simamora, R. H. (2011). ROLE CONFLICT OF NURSE RELATIONSHIP WITH PERFORMANCE IN THE EMERGENCY UNIT OF HOSPITALS RSD DR. SOEBANDI JEMBER. The Malaysian Journal of Nursing, 3(2), 23-32.Suzana Indragiri. 2018. Manajemen Risiko K3 Menggunakan Hazard Identification Risk Assessment and Risk Control (HIRARC). Jurnal Kesehatan. Vol. 9 No. 1

Tukatman., Sulistiawati., Purwaningsih., \& Nursalam. 2015. Analisis Keselamatan Dan Kesehatan Kerja Perawat Dalam Penanganan Pasien Di Rumah Sakit Benyamin Guluh Kabupaten Kolaka. Jurnal Ners Vol. 10 No. 2.

Widiwati Rinjani Octavia, A.T Diana Nerawati, Ernita Sari. 2018. Penerapan Pelayanan Kesehatan dan Keselamatan Kerja Pada Perawat IGD Rumah Sakit Umum DR.Wahidin Sudiro Husodo Mojokerto Tahun 2017. Gema Kesehatan Lingkungan. Vol 16 No. 1 